\title{
Exacum alberti-grimaldii Wohlh. \& Callm. (Gentianaceae), a new species endemic to northern Madagascar
}

\author{
Sébastien Wohlhauser \& Martin W. Callmander
}

\begin{abstract}
WOHLHAUSER, S. \& M. W. CALLMANDER (2012). Exacum albertigrimaldii Wohlh. \& Callm. (Gentianaceae), a new species endemic to northern Madagascar. Candollea 67: 373-378. In English, English and French abstracts.

Exacum alberti-grimaldii Wohlh. \& Callm. (Gentianaceae), a new species endemic to northern Madagascar, is described and illustrated. It resembles morphologically two other species: Exacum dolichantherum Klack. and Exacum nossibense Klack., also endemic to Madagascar. The three species have in common verticillated upper leaves and umbella-shape inflorescence. The new species can, however, be easily recognized by its smaller discrete petals and by the absence of wings on the sepals. It is known only from the Ampantsona river watershed in the Andrafiamena region in semi-decidous or sclerophyllous forests.
\end{abstract}

\section{Key-words}

GENTIANACEAE - Exacum - Andrafiamena - Madagascar - Taxonomy - Conservation

\begin{abstract}
Résumé
WOHLHAUSER, S. \& M. W. CALLMANDER (2012). Exacum albertigrimaldii Wohlh. \& Callm. (Gentianaceae), une nouvelle espèce endémique du nord de Madagascar. Candollea 67: 373-378. En anglais, résumés anglais et français.

Exacum alberti-grimaldii Wohlh. \& Callm. (Gentianaceae), une nouvelle espèce du nord de Madagascar, est décrite et illustrée. Elle ressemble morphologiquement à deux autres espèces endémique de Madagascar: Exacum dolichantherum Klack. et Exacum nossibense Klack. Les trois espèces ont en commun des feuilles supérieures verticillées et une inflorescence en ombelle. La nouvelle espèce peut cependant facilement être reconnue à ses petits pétales discrets et l'absence d'aile sur les sépales. Elle n'est connue que du bassin-versant de la rivière Ampantsona dans la région d'Andrafiamena dans les forêts semi-décidues et sclérophylles.
\end{abstract}

Addresses of the authors: SW: Association Fanamby, Lot II K 40, Ankadivato, MG-101 Antananarivo, Madagascar. Email: s.wohlhauser@gmail.com

MWC: Missouri Botanical Garden, P.O. Box 299, St. Louis, Missouri, 63166-0299, U.S.A. and Conservatoire et Jardin botaniques de la Ville de Genève, CP 60, CH-1292 Chambésy, Genève, Switzerland. 


\section{Introduction}

The paleotropical genus Exacum L. currently includes 70 species with a distribution that ranges from Africa to Australia with three main centres of diversity: Madagascar (39 spp.) (Wohlhauser \& al., 2005), India-Sri-Lanka (18 spp.) and Arabian Peninsula (5 spp.). Since KLACKenBerg (1985) published the Exacum monography, eight species have been added to the genus. Following a molecular phylogeny (YUAN \& al., 2003), four Cotylanthera Blume species from the Indian subcontinent were transferred to Exacum (KLACKENBERG, 2006). In addition, four new species have been described: E. decapterum Klack. from Madagascar (KLACKENBERG, 1990); E. arabicum Thulin from Yemen and Oman (THulin, 2001); E. klackenbergii Gopalan from India (GopALAN, 2002), and E. darae Hul from Vietnam (HuL, 2010).

The genus Exacum consists of both annual and perennial species. The highest diversity is encountered in annual species and most perennial species are known from Madagascar and the Indian subcontinent. Perennial species are mostly encountered in natural forests and rocky outcrops; annual species inhabit seasonally humid places, usually in low vegetation and open areas, from sandy river beaches to swampy coastal areas or muddy pastures from sea-level to mid-elevation (WOHLHAUSER \& al., 2005). Several annual species have restricted distribution in Madagascar: E. appendiculatum Klack. is endemic from the sandstone of Isalo in the south-western of Madagascar and E. conglomeratum Klack. is restricted to the rocky area of the Andringitra massif in the southern part of highlands (KLACKENBERG, 1990).

The Andrafiamena ridge in northern Madagascar is a transitional dry area showing a gradient of different forests types on diverse substrates (limestone-sandstone). This region is home to the Critically Endangered Perrier's Sifaka (Propithecus perrieri) (RANAIVOARISOA \& al., 2006; BANKS \& al., 2007) and therefore of high conservation concern (BURIVALOVA, 2011). Thanks to the establishment of monitoring facilities for the management of the Andrafiamen-Andavakoera Protected Area, currently under creation by Fanamby NGO, botanical inventories have been completed in this region. Among the recent collections issued from these inventories, one specimen was directly recognized as a yet unknown species of Exacum considering its small size and morphological characters.

In the present article, we describe a new species E. albertigrimaldii Wohlh. \& Callm., endemic from the AndrafiamenaAndavakoera region in northern Madagascar (Fig. 1). The new species is provided with preliminary risk assessments based on the IUCN Red List Categories and Criteria (IUCN, 2001). Calculations of the Area of Occupancy (AOO), Extent of Occurrence (EOO) and number of subpopulations were based on the methods presented in CALLMANDER \& al. (2007). A discussion of its morphological affinities is provided.

\section{Exacum alberti-grimaldii Wohlh. \& Callm., spec. nova} (Fig. 2-4).

Typus: Madagascar. Prov. Antsiranana: Fkt. Andrafiabe, chaîne d'Andrafiamena, bassin-versant d'Ampantsona, falaises gréseuses en forêt de transition, $12^{\circ} 55^{\prime} 10^{\prime \prime S} 49^{\circ} 21^{\prime} 13^{\prime \prime} \mathrm{E}$, $650 \mathrm{~m}, 1 . \mathrm{V} .2007$, fl. \& fr., Wohlhauser \& Bongary 803 (holoG [G0036900]!; iso-, K!, MO!, P [P00722549]!, TAN!).

Haec species quoad folia superiora verticillata etiam inflorescentiam umbraculiformem Exaco dolichanthero et E. nossibensi similis, sed a hoc sepalis exalatis, ab illo petalis discretis minoribus $(2-3 \times 1-1.5$ vs 3-7 $\times 2-4 \mathrm{~mm})$ facile distinguitur.

Annual erect herb, unbranched, $3-13 \mathrm{~cm}$. Stem quadrangular, with inconspicuous membranous wings, without nodes (exceptionally 1 node), often with 2 cotyledons at base. Any parts of the plants may be reddish due to the presence of anthocyanin in shadow habitats. Leaves not amplexicaulous, (2-) 3 pairs, opposite-decussate, with generally sub-verticillate aspect, shape variable depending on plant size and position of leaves; proximal pair of leaves sometimes on a lower node on the stem or absent, broadly ovate, narrowly attenuate at base, obtuse (sometimes rhomboid, orbicular or obcordate), (5-)10 $(-15) \times(2-) 5(-7) \mathrm{mm}$, lamina herbaceous, with $1-3$ nerves diverging from base; medium pair of leaves generally large, subsessile, cordate, $(4-) 15(-25) \times(3-) 10(-15) \mathrm{mm}$, lamina herbaceous, with 3-5(-7) nerves diverging from base; distal pair of leaves generally reduced, very variable in size, shape and color (reddish), ovate to lanceolate, (5-)20(-37) $\times(3-) 10$ $(-28) \mathrm{mm}$, lamina herbaceous to membranaceous, with $1(-3)$ nerves diverging from base. Flowers (1-)5(-14) in umbel-shaped,

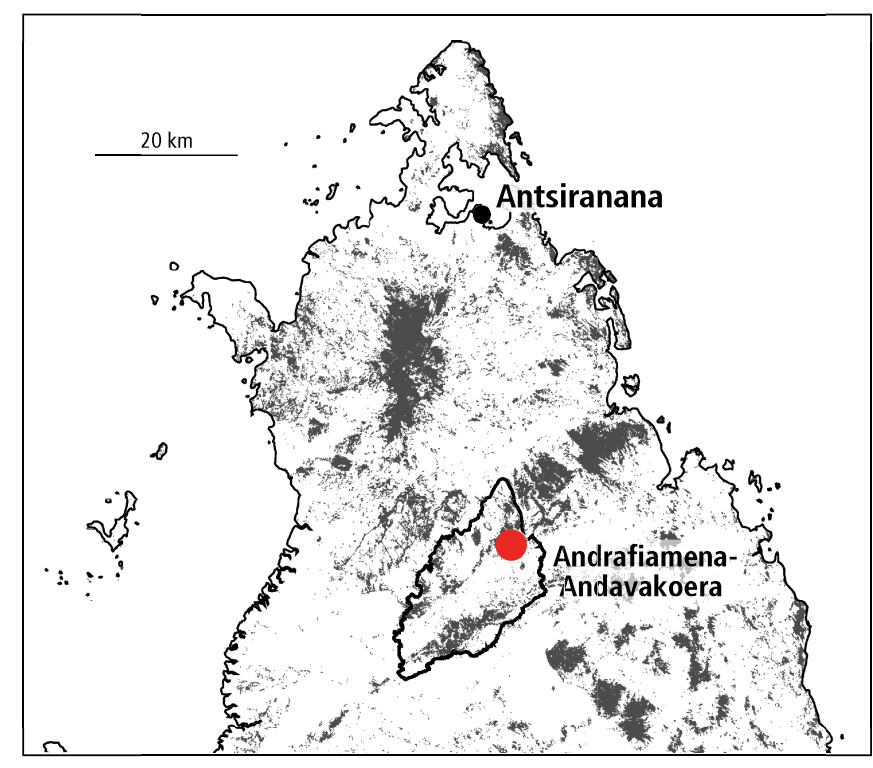

Fig. 1. - Map of Northern Madagascar with the locality of the type collection (star) within the proposed boundary of the Andrafiamena-Andavakoera protected area (Grey shadow, corresponding to remaining primary forest). 


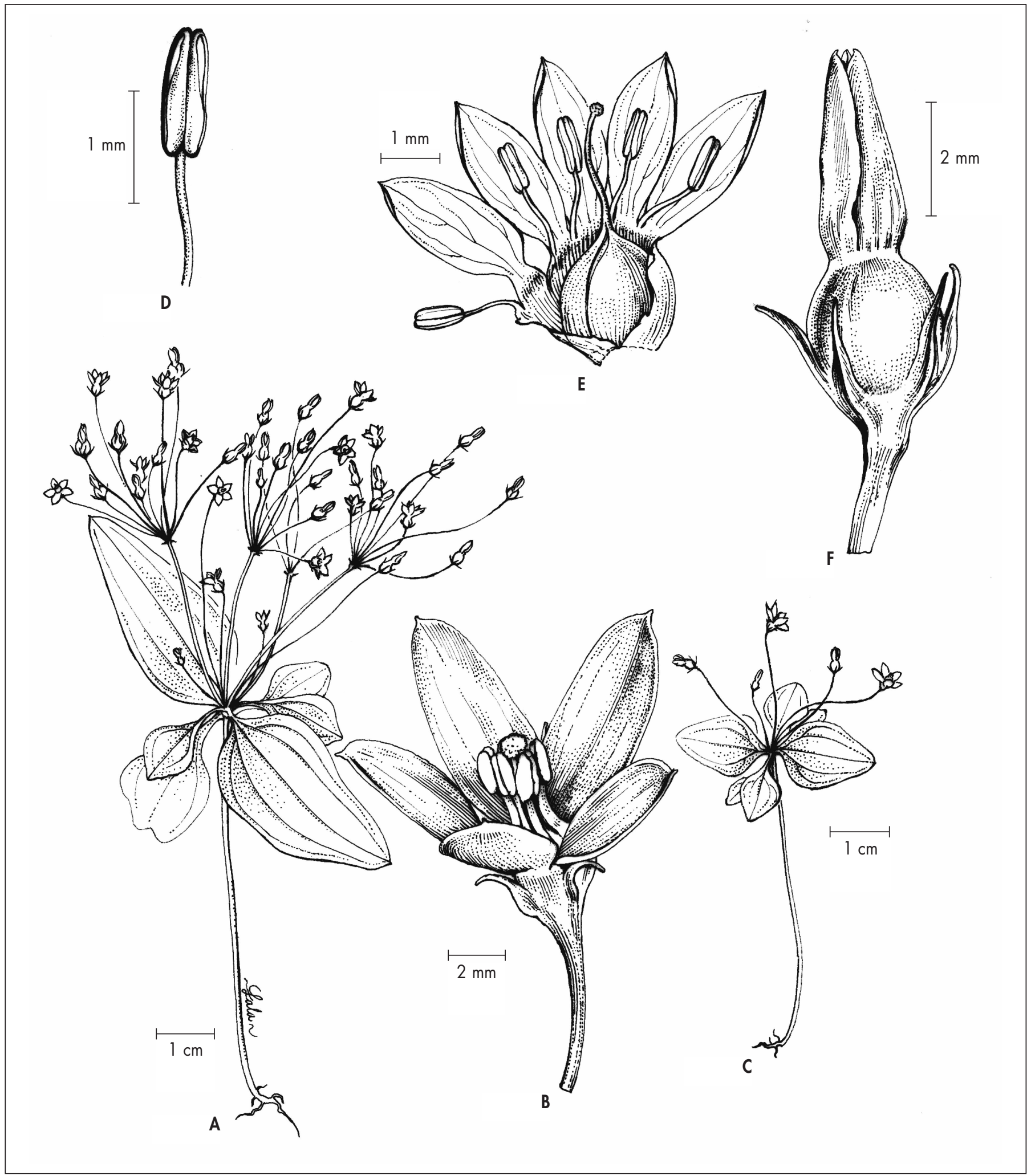

Fig. 2. - Exacum alberti-grimaldii Wohlh. \& Callm. A. Habitus of a multi-umbellated individual; B. Flower; C. Habitus of an individual with single umbel; D. Stamen; E. Flower with calyx removed; F. Detail of an autogamous flower.

[Wohlhauser \& Bongary 803, G, TAN] [Drawing: Roger Lala Andriamiarisoa] 


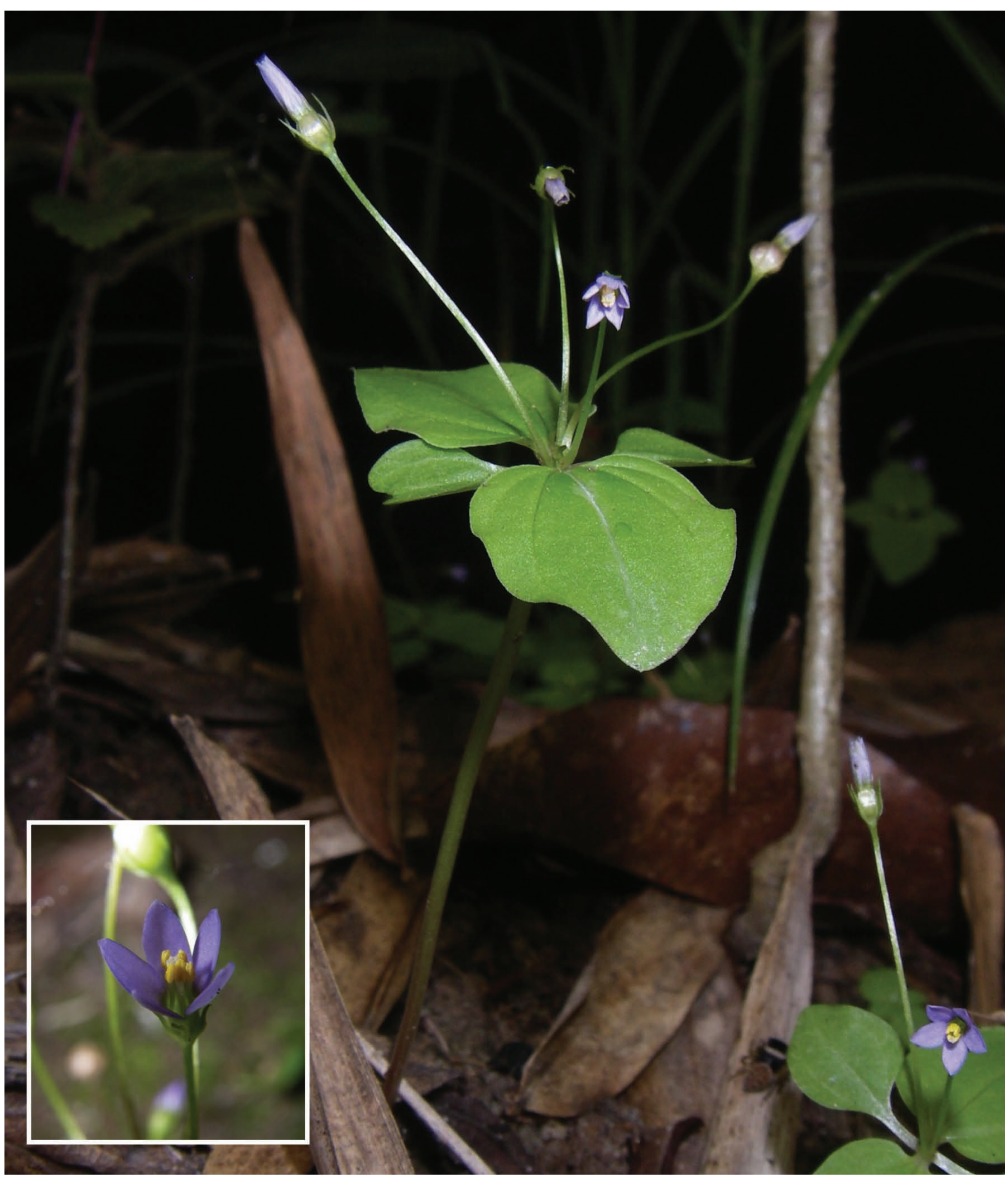

Fig. 3. - Flowering plant of Exacum alberti-grimaldii Wohlh. \& Callm. with detail of a flower (framed). [Wohlhauser \& Bongary 803] [Photo: S. Wohlhauser] 


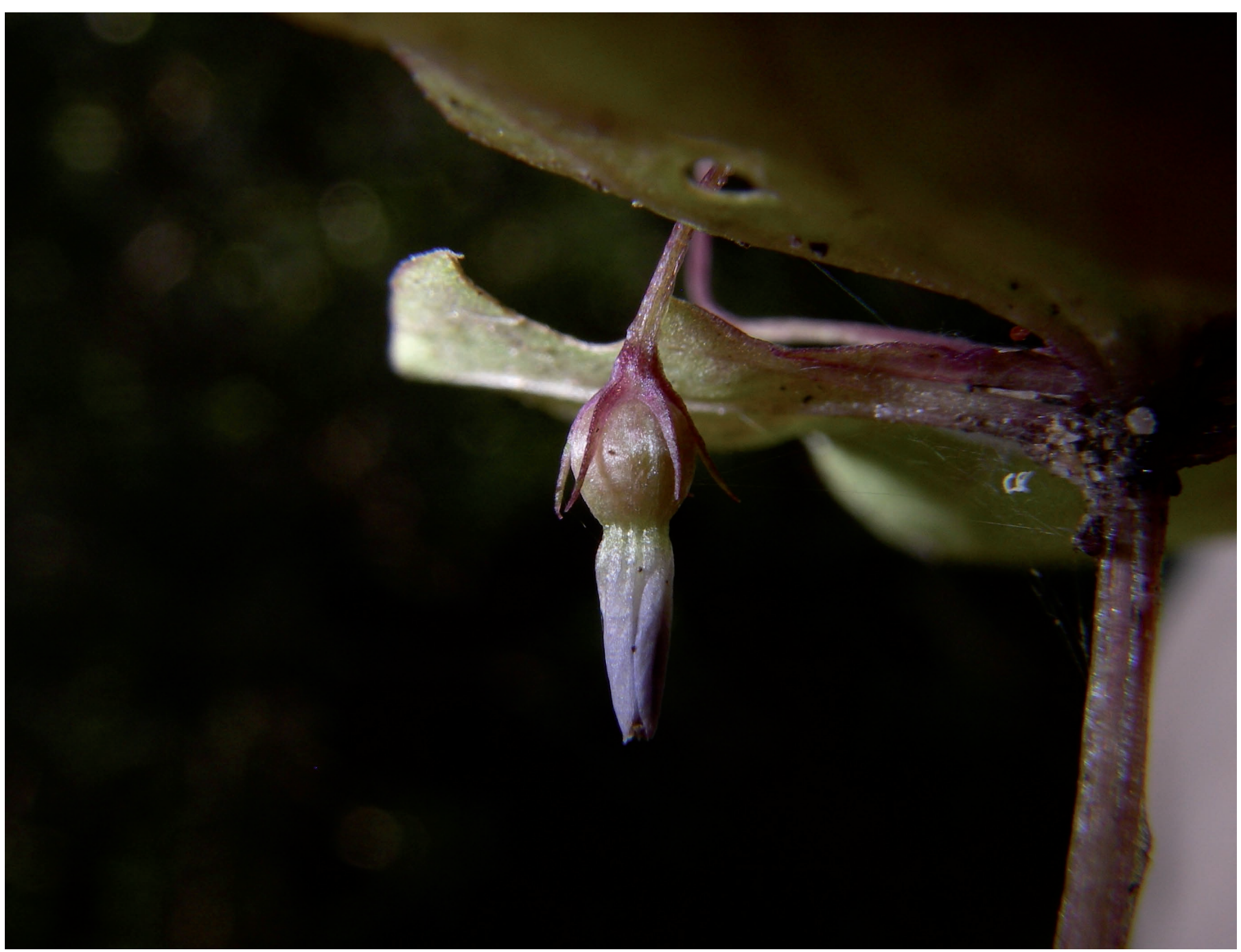

Fig. 4. - An autogamous flower of Exacum alberti-grimaldii Wohlh. \& Callm. showing the unwinged sepals.

[Wohlhauser \& Bongary 803] [Photo: S. Wohlhauser]

generally simple condensed cymes inflorescences, if composed 7-15 flowers per umbellule; pedicels (15-)25(-36) mm, erect at maturity, possibly cleistogamous (then reflected below the leaves). Calyx 5-lobed, the lobes shortly fused at base $(<1 / 5$ of the length), 1.5-2.5 mm, linear, not winged, acuminate, accrescent in fruit. Corolla 5-lobed, light blue, white in throat, fused in the lower fourth, 2-3 $\times 1-1.5 \mathrm{~mm}$, obovate, obtuse, acuminate, when withered with lobes forming a cone at the top of the capsule, accresent. Stamens 2-3 mm long; anthers c. $1 \mathrm{~mm}$, yellow, rectangular, curved and slightly narrowing towards the apex, without papilla near the apex, opening by pores that later widen to slits along up to $1 / 2$ of the anther length. Styles as long as the stamens. Fruit a sub-spherical capsule, 1.5-2 $\mathrm{mm}$ in diam., coriaceous, with accresent sepals appressed to the distal part of withered corolla, septicidally 2-valved with the partial septum.
Etymology. - The species is named in honour of Albert II de Monaco, Albert Alexandre Louis Pierre Grimaldi, Prince of Monaco, in recognition of his tireless support to the NGO Fanamby for their conservation activities in Northern Madagascar, especially in the Andrafiamena region where the species seems to be endemic.

Distribution and ecology. - Exacum alberti-grimaldii is only known from the Ampantsona river watershed occurring on seeping sandstone outcrops or on temporary humid river banks in semi-deciduous or sclerophyllous forest. It is an annual species completing its life-cycle in less than two and half months between March and May.

Conservation status. - Exacum alberti-grimaldii has been observed only three times in the Ampantsona valley and collected only once. With only one collection and three known 
subpopulations, an $\mathrm{AOO}$ of $>9 \mathrm{~km}^{2}$ within the Protected Area under creation of Andrafiamena-Andavakoera and according to its annual life-cycle and rarity of proper habitats, E. albertigrimaldii is assigned a preliminary status of Vulnerable (VU D2) following IUCN Categories and Criteria (IUCN, 2001).

Notes. - Only two other species are characterized by verticillated upper leaves and umbella-shape inflorescence: E. dolichantherum Klack. and E. nossibense Klack. (KLACKENBERG, 1985: 94; Fig. 69, 96, 71). Exacum alberti-grimaldii can be easily distinguished from $E$. dolichantherum by its smaller discrete petals $(2-3 \times 1.0-1.5 \mathrm{~mm}$ vs $3-7 \times 2-4 \mathrm{~mm}$ for $E$. dolichantherum) and from E. nossibensee by the absence of wings on the sepals (Fig. 2-4). The new species grows in a dry transition area on diverse substrates (limestone-sandstone) whereas $E$. dolichantherum grows in open areas on sand along the littoral of the east coast and E. nossibensee is endemic from the Sambirano Domain sensu HuMBERT (1955) on diverse substrates.

\section{Acknowledgements}

The authors thank Serge Rajaobelina (NGO Fanamby, Antananarivo, Madagascar) and Patrick Ranirison. We thank the "Ministère de l'Environnement et des Forêts" in Madagascar and Monaco's International Cooperation and Development office for the fruitful collaboration in establishing the newly Protected Area of Andrafiamena-Andavakoera where the species seems to be endemic. We are also grateful to Roger Lala Andriamiarisoa for the fine illustrations, Roy Gereau for the Latin diagnosis and nomenclatural advises about the species name and the local communities that participated in the fieldwork. Financial support was provided to MWC by the Andrew W. Mellon Foundation.

\section{References}

Banks, M. E., E. R. Ellis, Antonio \& P. C. Wright (2007). Global population size of a critically endangered lemur, Perrier's sifaka. Anim. Conservation 10: 254-162

Burivalova, Z. (2011). Remote sensing of vegetation in conservation. A case study from the dry and transitional forests of Andrafiamena, Northern Madagascar. Master's Dissertation. University of Geneva \& Conservatoire et Jardin botaniques of the City of Geneva.

Callmander, M. W., G. E. Schatz, P. P. Lowry II, M. O. Laivao, J. RAHARIMAMPIONONA, S. ANDRIAMBOLOLONERA, T. RAMINOSOA \& T. Consiglio (2007). Application of IUCN Red List criteria and assessment of Priority Areas for Plant Conservation in Madagascar: rare and threatened Pandanaceae indicate new sites in need of protection. Oryx 41: 168-176.
Gopalan, R. (2002). A new species of Exacum L., Gentianaceae, from Agasthiyamalai (Pothigai), southern Western Ghats, India. J. Bombay Nat. Hist. Soc. 99: 271-273.

HuL, S. (2010). Two new species of Gentianaceae from Indo-China. Edinburgh J. Bot. 67: 155-160.

HumBerT, H. (1955). Les territoires phytogéographiques de Madagascar. Année Biol. 31: 439-448.

IUCN (2001). Categories and Criteria (version 3.1). IUCN, Gland and Cambridge.

Klackenberg, J. (1985). The genus Exacum (Gentianaceae). Opera Bot. $84: 1-144$.

Klackenberg, J. (1990). Gentianacées. In: Morat, P. (ed.), Fl. Madagascar \& Comores 168. Muséum national d'Histoire naturelle, Paris.

KLACKENBERG, J. (2006). Cotylanthera transferred to Exacum (Gentianaceae). Bot. Jahrb. Syst. 126: 477-481.

Ranaivoarisoa, J. F., R. Ramanamahefa, E. E. Louis JR. \& R. A. Brenneman (2006). Range extension of Perrier's Sifaka, Propithecus perrieri, in the Andrafiamena Classified Forest. Lemur News 11: 17-21.

Thulin, M. (2001). Exacum (Gentianaceae) on the Arabian Peninsula and Socotra. Nordic J. Bot. 21: 243-248.

Wohlhauser, S., P. KÜPfer \& Y.-M. YuAN (2005). Gentianaceae Family in the Madagascar region. In: Goodman, S. M. \& J. BENSTEAD (ed.), The Natural History of Madagascar: 409-415. University of Chicago Press.

Yuan, Y.-M., S. Wohlhauser, M. Möller, P. Chassot, G. Mansion, J. Grant, P. Küpfer \& J. Klackenberg (2003). Monophyly and relationships of the tribe Exaceae (Gentianaceae) inferred from nuclear ribosomal and chloroplast DNA sequences. Molec. Phylogen. Evol. 28: 500-517.

Yuan, Y.-M., S. Wohlhauser, M. Möller, J. KlackenberG, M. W. CAllmander \& P. KÜPFER (2005). Phylogeny and biogeography of Exacum (Gentianaceae): A disjunctive distribution in the Indian Ocean basin resulted from long distance dispersal and extensive radiation. Syst. Biol. 54: 21-34. 